MÉSZÁROS ZSOLT ${ }^{1}$

\title{
HELYZETKÉP A MAGYAR DIVATTÖRTÉNETI KUTATÁSOKRÓL
}

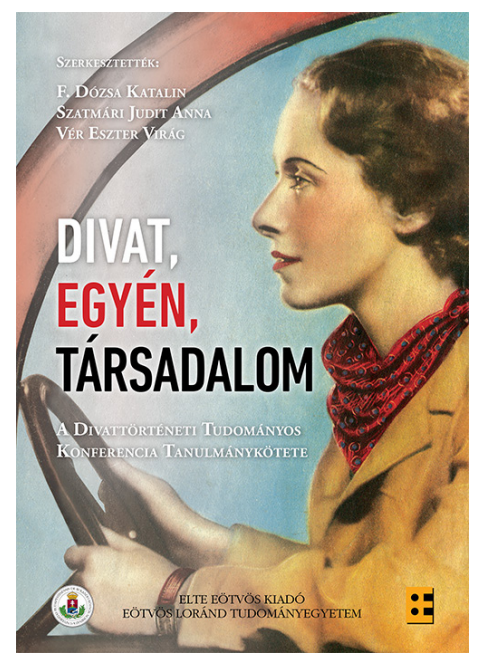

F. Dózsa Katalin - Szatmári Judit Anna - Vér Eszter Virág (szerk.) (2016) Divat, egyén, társadalom

A divattörténeti tudományos konferencia tanulmánykötete

Budapest: ELTE Eötvös Kiadó

DOI: 10.18030/sOCIO.HU.2017.2.81

A tanulmánykötet és előzménye, az ELTE BTK kampuszán 2015 novemberében rendezett konferencia a szervezők megfogalmazása alapján kettős célt szolgál: egyrészt felmutatni a hazánkban jelenleg folyó divattörténeti kutatások sokféleségét, másrészt az olvasóközönséget meggyőzni arról, hogy a divattörténet önálló tudományág. Tehát a konferencia és az előadások válogatott anyagát tartalmazó kiadvány nemcsak a magyar divattörténet létezését, hanem létjogosultságát is bizonyítani kívánja, megközelítéseinek, önálló kutatási módszereinek, eredményeinek és lehetőségeinek felsorakoztatásával. Bár a tanulmánykötet bevezetője szerint a 2015-ös konferencia volt az „első egyetemi tudományos divattörténeti konferencia” Magyarországon, műfajában mégsem előzmény nélküli: gondolhatunk itt a Kirakat: Divat a szocializmusban címú kiállítást kísérő nemzetközi konferenciára (2007), vagy a Street Fashion Budapest címú projekt részeként megvalósuló szintén nemzetközi tanácskozásra (2011). ${ }^{2}$ Mindazonáltal a 2015-ös konferencia és az ahhoz kapcsolódó Divat, egyén, társadalom című tanulmánykötet közreműködőinek szándéka világosan kirajzolódik: közös fellépés, hogy deklarálják a nyilvánosság előtt a divattörténet helyét és jelentőségét az akadémiai, egyetemi világban.

A divat története, ahogy a francia divattörténészek új nemzedékének két jeles képviselője, Maude BassKrueger és Sophie Kurkdjian fogalmazott, mindenekelőtt a kapcsolódások, a cserék és a cirkulációk története anyagi és szellemi értelemben egyaránt. ${ }^{3}$ A nemzetközi kutatások a divatot a modernitás részének tekintik, és

1 Irodalom- és múvészettörténész kutató

2 Az egyetemi előzmények között megemlítendő Hermann Veronika divatelméleti kurzusa az ELTE Média és Kommunikáció Tanszékén, és az ahhoz kapcsolódó Glass what című projekt (Antal Nikolett, Hermann Veronika, Juhász Dóra, Rákóczi Balázs). Továbbá a 2015-ös divattörténeti konferencia utózmánya az ELTE Történeti Intézet Múvelődéstörténeti Tanszéke és a Történelem Segédtudományai Tanszék szervezésében megvalósuló A divat és a divatipar története a 19-20. században - Forráshasználat a divattörténet kutatása és a tárgyak feldolgozása során címú divattörténeti kurzus (2015-2016. II. félév), amelyen a jelen kötet szerzői közül többen is előadtak.

3 „L'histoire de la mode est avant tout une histoire de contacts, d'échanges, de circulations matérielles de vêtements et tissus, et immatérielles d'individus et d'idées" (Bass-Krueger-Kurkdjian 2016:113). 
rámutatnak technikai, gazdasági, ipari, politikai, társadalmi, kulturális kötődéseire. Ezzel összhangban a jelen kötet szerzői is szélesebb összefüggésrendszerben vizsgálnak ruhadarabokat, öltözködési és fogyasztási szokásokat, tervezői munkásságot, textilipari és kereskedelmi folyamatokat a 19. és a 20. századra vonatkozóan. A tanulmányok tematikailag és módszertanilag változatos képet mutatnak, a hazai szakirodalomban eddig uralkodó szociológiai, történeti-múvészettörténeti, valamint néprajzi megközelítés mellett média- és kultúraelméleti belátások, pszichológiai szempontok is megjelennek.

A tanulmánykötetet F. Dózsa Katalin kutatástörténeti összefoglalója nyitja, ami áttekinti a régi korok viseletei iránti érdeklődés kialakulásának, valamint a divat történeti feldolgozásának folyamatait, főbb állomásait a reneszánsztól egészen napjainkig. A szerző kitér az eszmei és múvészeti áramlatok, a színház, a képzőművészet, a társasági élet (jelmezes események) szerepére is, hiszen a kosztümtörténeti könyvek segédeszközül szolgáltak és szolgálnak a képzőmúvészek, a rendezők, a színészek, a szabók számára is. Mindazonáltal F. Dózsa bevallott célja tanulmányával e diszciplína önállósulásának és intézményesülésének bemutatása mellett „a viselettörténet iránt érdeklődőket segíteni a könyvek megismerésében" (23). Ennek jegyében a viselettörténet tudományos korszakainak szemléjét a 17. századtól indítva, egyfajta annotált, kommentált bibliográfia formájában röviden jellemzi az angol, francia, német nyelvű szakmunkákat forráskezelésük, képjegyzékük, ruhaleírásaik, adataik alapján; melyik megbízható, melyik nem, melyik használható ma is, és melyik kevésbé. Helyenként talán túl sommás az értékelés, bár kétségkívül figyelembe kellett venni a terjedelmi korlátokat. Fontos hangsúlyozni a tanulmány hazai szempontból hiánypótló voltát, mert beillesztve a nemzetközi kontextusba, a magyar divattörténet-írás historiográfiai vázlatát is nyújtja.

A divattörténet módszertanával kapcsolatban F. Dózsa három múveletet emel ki: az eredeti mútárgyakon alapuló precíz ismertetést, a datálást, valamint a divatváltozások felmérését. Ugyanakkor arra is figyelmeztet, hogy egy-egy korszak divatját el kell tudni helyezni saját korában. A szélesebb kontextus mellett rámutat a ruhák személyhez és családhoz kötődő kontextusának fontosságára (használat, öltözködési szokások, emlékek, hagyományok), az annak feltárását segítő provenienciakutatás ${ }^{4}$ és interjúk (oral history) szükségességére. Mindehhez pedig hozzátartozik az a felismerés, hogy „„a jó ruha csak a testtel együtt válhat akár múvészeti alkotássá” (43). ${ }^{5}$

A divattörténeti kutatások számára nélkülözhetetlen képi források jelentőségét, valamint a hitelesség és a datálás problematikáját vizsgálja Borovi Dániel Erzsébet királynéról szóló tanulmánya. Elsőre meglepőnek hathat, hogy bár Erzsébetet divatikonként tartják számon, nem sok öltözéke maradt fenn. Gardróbjának és öltözködési szokásainak rekonstruálásához a korabeli leírások, fotók, képzőművészeti alkotások szolgálnak információval, amiket viszont kritikával kell kezelni. Erre jó példa Erzsébet magyar koronázási díszruhájának esete, amit Borovi tanulmányának első részében részletesen elemez. Az öltözék nem maradt fenn, és a helyzetet bonyolítja, hogy nem ismerünk olyan fényképet, amely a koronázási szertartás közben készült volna Erzsébetről. Emil Rabending 1867-re datált mútermi fotósorozatáról gondolták azt sokáig, hogy azon Erzsébet a magyar koronázási díszöltözékben jelenik meg, de az újabb kutatások kiderítették, hogy a felvételek 1866 tavaszán készültek. Mindenesetre ez a fotósorozat vált a magyar koronázási ruha gyakori képi forrásává, aminek különféle

4 Az adott tárgy eredetének, származásának tisztázása, tulajdonosainak kiderítése, történetének rekonstruálása.

5 A ruha, az eltúnt test, a jelenlét és az emlékezet összetett viszonyának kérdése Olivier Saillard, a Palais Galliera, azaz a párizsi divatmúzeum igazgatója performanszaiban, nyilatkozataiban és írásaiban is rendre előkerül. 
mértékű újrafelhasználásait Borovi nyomon követi a későbbi koronázási díszruhás Erzsébet-portrékon. Továbbá kitér arra a fekete díszmagyarra is, amit a királyné a millenniumi ünnepségeken viselt.

Írásának második részében pedig azokat az Erzsébet-portrékat veszi szemügyre, amelyeket Ferenc József rendelt meg a felesége halála után. Ezek azért lehetnek viselettörténeti források, mert a festők munkájukhoz megkapták a királyné eredeti ruháit, sőt, Horovitz Lipót még a szabóbábuját is. Mindezeken túlmenően Borovi tanulmánya az Erzsébet-kultusszal, az uralkodói reprezentációval, a portréfestészet hátterével, a személyi ikonográfia kialakulásának folyamataival, és a képek korabeli cirkulációjával, hibridizációjával kapcsolatban is értékes adalékokkal szolgál.

A ruha családi vonatkozásaival foglalkozik Kollár Csilla, mégpedig egy jól ismert hazai gyáros-dinasztiához kötődően. Két 1882-ben készült mútermi felvételt vizsgál, az egyik képen Zsolnay Júlia, a másik képen pedig öccse Miklós látható reneszánsz jelmezben. Maguk a ruhák nem maradtak fenn, így Kollár a fényképekből kiindulva tárja fel a hozzájuk kapcsolódó alkalmat, reprezentációs stratégiákat, kreatív hátteret, családi és a gyári környezetet. Illemtankönyvek, tanácsadó írások, sajtóbeszámolók segítségével elemzi a jelmezbálok helyét, szerepét, fő jellemzőit a korabeli társasági életben, valamint részletesen leírja a konkrét eseményt, azt az 1882 telén, Munkácsy tiszteletére rendezett jelmezbált, amelyen a Zsolnay-testvérek a fényképeken megörökített kosztümjeiket viselték. A szerző a Zsolnay-gyár egyik tervezője, Klein Ármin által jegyzett ruhák előképeit kimutatja a gyár termékein, amelyeken visszatérően felbukkannak reneszánsz és németalföldi alakok.

Kollár tudatos döntésnek tartja a Zsolnay-testvérek jelmezválasztását, aminek üzenetértéke van, mivel reprezentatív eseményen jelentek meg benne. Egyrészt megfeleltek a jelmezbál követelményeinek (történelmi hűség), másrészt azáltal, hogy alkalmazottjuk készítette öltözékeiket, ami megidézi a Zsolnay-dísztárgyak ábrázolásait, saját cégüket is képviselték. A szerző rámutat a két jelmez üzleti, marketing és múvészi aspektusaira, amellett, hogy a családi összetartás példájaként értelmezi.

Szatmári Judit Anna tanulmányában a tervezői oldalt mutatja be. A Magyar Divatipar címú, a Nőiruhakészítók Országos Szövetségének (NOSz) hivatalos lapjában azt vizsgálta, hogy a pesti divatszabók az 1920-as években hogyan tekintettek magukra és a szakmájukra, összehasonlítva a párizsi haute couture mesterekkel, akiknél az alkotás, a fantázia és a magas társadalmi presztízs kapott hangsúlyt. Ez az időszak azért is érdekes, ahogy Szatmári rámutat, mert az I. világháború után vagyunk, amikor megváltozott körülmények között kellett a hazai divatiparnak talpra állnia; újra felvették a kapcsolatot a francia divatházakkal, és új kihívásokkal kellett szembenézniük. Például nehezítették a múködésüket a behozatali korlátozások, továbbá erős volt a verseny Béccsel.

A tanulmány erénye nemcsak az, hogy alaposan és érdekfeszítő módon tárja fel a lapban, illetve a NOSz múködésében érvényesülő iparos szemléletet, a szabóipar jogi hátterét, az érdekvédelmi törekvéseket, a kartársi támogatás formáit, hanem az is, hogy rámutat a korabeli hazai divatszcéna újraszerveződésének és önmeghatározási törekvéseinek mozzanataira. Megtudhatjuk, hogy a pesti szabók elismerték a párizsi irányítást, és elsősorban arra törekedtek, hogy minél közvetlenebb, minél jobb legyen a kapcsolat az ottani divatcégekkel. Mindemellett saját tervezői tevékenységre is akadt már példa (pl. Fischer Júlia és Társa, Sidy szalon, Berkovits). A szakma hazai társadalmi megítélése nem volt túlságosan megbecsült, ezt illusztrálja a Magyar Divatiparban 
egy pályakezdő szabónő tollából megjelent 1927-es cikk, amiben a szabók klienseikkel szembeni alárendelt szerepére hívja fel a figyelmet. ${ }^{6}$ Viszont nem csüggedt el, hanem arra buzdította szaktársait, hogy változtassanak ezen, és munkával, szaktudással teremtsék meg a maguk márkáját. Szatmári konklúziója szerint, az 1920-as években a pesti divatszabóknál az iparos identitás túnik erősebbnek, de a Párizstól való függés mellett már a helyi önálló tervezés, illetve a múvészi-alkotói ambíció is megjelent és erősödött Magyarországon.

Fülemile Ágnes ugyanígy egy a két világháború közötti időszakban alkotó magyar divattervező, Kárász Mariska munkásságát dolgozza fel, aki amellett, hogy az Egyesült Államokban futott be fényes karriert, egyedi tervezői stílusában invenciózusan ötvözte az avantgárd szemléletet az amerikai modernizmussal és az etnikus tradícióval. A szerző Kárász Mariska egy konkrét, kétrészes, szűrmotívumokra emlékeztető, fehér applikációkkal díszített tengerészkék selyemkosztüméből (1927) indul ki, amelyet a New York-i Metropolitan Museum of Art Costume Institute őriz. Precízen feltárja a ruha társadalmi, kulturális és művészi kontextusait, kitérve a megrendelő társadalmi helyzetére, valamint alkotójának életútjára, munkásságára, amit saját kutatások és a szúkös szakirodalom alapján rekonstruált. Számomra a kötet egyik legszínvonalasabb és legizgalmasabb tanulmánya, mert nem csak egy elfeledett figurát porol le, és helyez vissza a korába, hanem több oldalról is körüljárva a témát, komplex elemzői módszerekkel újraértékeli az életmúvet, és rámutat ma is érvényes kvalitásaira, designés divattörténeti relevanciájára.

Kárász önálló divatszalonja az 1920-as és 1930-as években élte aranykorát, majd, amikor 1941-ben tűzben elpusztult a szalon (a raktárkészlettel és a dokumentációval együtt), profilt váltott, és textilmúvész lett, amely minőségében szintén sikereket ért el. Divattervezői munkásságában nemcsak a magyar népi ornamentikából, hanem afrikai, mexikói, kínai, indián motívumokból is ihletet merített. Továbbá, Fülemile végigveszi azokat a mozzanatokat, hatásokat, folyamatokat, amelyek közrejátszottak Kárász Mariska egyedi életművének formálódásában: például a hazulról hozott módszeres iparművészeti képesítés és a paraszti népmúvészet ismerete, a bécsi Wiener Werkstätte összmúvészeti koncepciója, a Greenwich Village bohém és inspiráló szellemi közege, az orientalizmus múlt század eleji divatja, az Európán kívüli kultúrák iránt felerősödő érdeklődés, vagy a „Designed in America” mozgalom.

Az írások másik része egy-egy divatkellékre fókuszál. Erdei T. Lilla a szecesszió egyik legkedveltebb divatdíszéről, a csipkéről értekezett. Világos összefoglalásában szisztematikusan áttekinti különféle típusait, az öltözékeken való felhasználásait, a hazai csipkeverés hagyományait, valamint a múlt századelőn létesülő, és külföldön is hamar ismertté váló manufaktúrák tevékenységét (pl. halasi, csetneki). Rámutat azokra a mozzanatokra, ahogy az állami oktatáspolitikának, a magánmúhelyeknek, és a szecesszió divatjának köszönhetően a gépi csipke, illetve a cseh import által kiszorított hazai kézi csipke újjászületik, és mind anyagi, mind pedig múvészi értelemben sikeressé válik.

6 A halászó macska uccája (1936) című regény Annája is hasonló tapasztalatot szerez, amikor Párizsból hazatérve, varrónőként elhelyezkedik egy pesti divatszalonban: „Kint-legalább eleinte - megvetették, lenézték, mert idegen volt, de foglalkozásának tiszteletreméltósága, mesterségbeli önérzete soha sérelmet nem szenvedett. Idehaza nem őt vetik meg, még valami különös kis egyéni tekintélye is van, mert Párizsban járt, de társadalmi helyzete csökkent, állásának az emberi közösségen belüli értéke szállt alá, az a megbecsülés, ami magát a szakmát illeti. Párizsban ő Mademoiselle Anne volt, már kezdő varrónő korában is az, Mademoiselle Anne vevőnek és fönöknönek, itt »Nézze, fiam«." (Földes é.n.:215). 
Csipes Antal gyűjtőszenvedélyének középpontjában a női táska áll. Ő maga számol be a mintegy 30 éve gyarapodó kollekciója fejlődéséről, gyűjtési szempontjairól (eltérő záródású keretes táskák), színes és feketefehér reprodukciókkal kísérve. Döntően 1945 utáni modellek találhatók a gyűjteményében, de kisebb százalékban 19. századi és két világháború közötti darabokat is őriz, amelyek anyagukban (fa, fém, bőr, textil, műanyag) és rendeltetésükben is (nappali, estélyi, pipere) roppant változatosak. Sőt, tartalmaz haute couture márkákat is (Yves Saint Laurent). Kétségkívül a tanulmánykötet egyik erénye, hogy egy különleges, nem közismert magángyűjteményt is bemutat a nagyközönségnek, ráadásul a gyűjtő magyarázataival kiegészítve.

Szentesi Réka a női fúzőviselés dualizmus kori vitáját vizsgálja a korabeli egészség-feminizmus-szépségideál kontextusában. Több szempontot bevonva, igyekszik megbontani a fűzőről kialakult egysíkú képet, és elsősorban társadalmi problémaként értelmezi. A 19. század második felében, illetve a múlt századfordulón felerősödő fúzőellenes diskurzust összefüggésbe hozza a modernitás testképével, a nőmozgalmak előretörésével, valamint a társadalom és az életmód megváltozásával. Kitér arra is, hogy a fúző státuszszimbólumként az úri létformához, a polgári nőeszményhez kötődött. Majd olyan színésznőkről készült, a korban közkézen forgó fényképeket vizsgál (Hegyi Aranka, Fedák Sári), amiken retussal érték el a darázsderekat. Ezáltal rámutat a színésznők szerepére a szépségideál terjesztésében, a róluk készült felvételekre, mint értékes forrásanyagra (vö. Buckley-Fawcett 2002:16-49), valamint arra, hogy „elsősorban egy testforma divatjáról, nem pedig egy ruhadarabéról van szó” (159). A fúző „kimúlásával” kapcsolatban hangsúlyozza, hogy a közhiedelemmel ellentétben nem egyik napról a másikra tűnt el, hanem átalakult; például gumifúző formájában élt tovább, hogy segítse a lapos, fiús testideál elérését.

Szentesi elemzése át is irányít bennünket a kötet azon írásaihoz, amelyek a divat társadalmi, politikai dimenzióit vizsgálják. Vér Eszter Virág gazdagon adatolt tanulmányában Erzsébet királyné öltözködési és vásárlási szokásairól, valamint magyaros viseleteiről ír, elsősorban az 1857-es és az 1866-os magyarországi császári látogatásokhoz kapcsolódóan. E két körút fogadtatásának és a Habsburg-udvar arculatváltó törekvéseinek rekonstruálásán keresztül vizsgálja Erzsébet megjelenéseinek szimbolikus szerepét, aminek jelentőségével egyébként maga a királyné is tisztában volt: öltözékeinek magyaros utalásai, vagy pesti vásárlásai hogyan szolgáltak politikai célokat, mennyiben járultak hozzá a politikai átalakuláshoz, az uralkodóház megítélésének változásához és saját kultuszának kialakulásához. A szerző gondosan alátámasztott érvelése szerint Erzsébet magyar ruhái a kezdeti időszakban kevésbé a szimpátia, vagy valamifajta személyes lázadás kifejeződéseinek tekinthetőek, hanem sokkal inkább uralkodói reprezentációként, illetve az udvar politikai terveként értelmezhetők.

Lukács Anikó a Férfidivat-közlöny esetében szintén a „magyar ruha” affektív-politikai oldalát veszi górcső alá. Tanulmánya abból a szempontból is üdvözlendő, hogy emlékeztet a férfiak divatfogyasztására, valamint a nekik szánt divatlapok létezésére, ezzel is megcáfolva azt a tévhitet, hogy a divat kizárólag „női bohóság” volna. Ugyanakkor a szerző nem a maszkulinitások és az öltözködés viszonyára, hanem a nemzeti viselet diskurzusára és a szabóiparosok törekvéseire összpontosít.

A Férfidivat-közlöny elsősorban szakmabelieknek szóló orgánum volt, amely a magyar szabóipar összefogását szorgalmazta a hazai ipar védelme és népszerűsítése érdekében, továbbá szakmai és üzleti tapasztalatcsere fórumaként kívánt múködni. A lapalapító, Jámbor Endre egész különleges pályát futott be: az 1862. évi 
Iondoni világkiállításon díjat nyert fejedelmi díszöltözetével, politikai összeesküvést szőtt, és elborult elmével halt meg. Közlönye, bár összeállításában pesti és vidéki szabók is részt vettek, lényegében egyszemélyes lapnak tekinthető, amelyben sajátos módon keveredtek egymással a nemzeti szólamok, a honi ipar védelmének és az önálló magyar divat eszméjének elemei, és Jámbor fantaszta gondolatai. Lukács a lap elemzése alapján rávilágít a 19. század közepi nemzeti divatmozgalom szabóipari és üzleti vetületeire: a korban népszerű, hazafias érzelmeket kifejező „magyar öltözet” készítése megélhetést biztosított a szabók számára.

Mintegy száz évet ugorva az időben, de még a politikai diskurzusoknál maradva, két szerző a kormányzati rezsim(ek) és a divat viszonyát tárgyalja. Valuch Tibor a 2. világháborútól egészen az ezredfordulóig tekinti át, és kísérli meg számba venni az öltözködési és divatfogyasztási szokások változásainak fő trendjeit. Négy időmetszetre osztja fel a 20. század második felét: 1945-1956, 1956-1968, az 1960-as évek végétől az 1980-as évek közepéig terjedő periódus, végül az 1980-as évek közepétől az ezredfordulóig tartó időszak.

Tanulmányában félszáz év panoramatikus képe bontakozik ki: politikai dresszúra, uniformizálódás, anyaghiány, lassú konszolidáció, a fogyasztói magatartás megjelenése és elterjedése, a tömegkommunikáció hatása, differenciálódó üzlethálózat, a vagyoni különbségek mélyülése, újraszerveződő társasági élet, öltözködési szabályok alakulása. Valuch a 2. világháborútól az ezredfordulóig tartó korszak öltözködés és divat változásaiban az egyes társadalmi csoportok azonosságtudatának, mentalitásának, viselkedésének változásait figyeli meg. Tézise szerint az öltözködés különböző mértékben, de „mindvégig a társadalmi reprezentáció fontos tere és eszköze maradt a magyar társadalomban a 20. század második felében” (247).

Simonovics Ildikó tanulmánya többek között arra hoz meggyőző bizonyítékokat a miniszoknya hazai recepcióját vizsgálva, hogy a politikai ideológia 1956 után csak látszólag vonult ki a divat területéről. Ha már nem is erőszakos eszközökkel, de a "szocialista (jó)ízlés” nevében továbbra is szabályozta, ellenőrzése alatt tartotta azt. Simonovics érvelése szerint, amíg az 1960-as évek ifjúságkultuszának (youthquake) nyomán a nemzetközi divatban a fiatal nő testesítette meg a szépségideált, addig nálunk az időtlen, klasszikus vonalat részesítették előnyben, és a középkorú nőt tették meg eszménynek.

A magyar divatdiskurzus a modernre és a célszerüre hivatkozva általában gúnyolódott a nyugati divatújdonságokon. Az ún. „szocialista jóízlés” alapjának a minden feltúnéstől való tartózkodást, a mértéktartást és a visszafogott megjelenést tartották; éppen ezért a magyar divatsajtó számára Chanel volt az etalon. Mindezek fényében nem meglepő, hogy a miniszoknya egyrészt késleltetve jelent meg a hazai divatsajtóban (Nők Lapja, Ez a Divat, Pesti Divat), másrészt inkább negatív megítélés alá esett. Simonovics amellett, hogy a miniszoknya hazai fogadtatástörténetének kezdetét, ideológiai komponenseit mutatja be, a szocialista szakmai divatdiskurzus körvonalazására és definiálására is gyümölcsöző kísérletet tesz.

Végezetül, de nem utolsósorban, a jelen tanulmánykötet két teoretikus szövege következzék. Antalóczy Tímea és Pörczi Zsuzsanna a pszichoanalízis szerepét boncolja a divat értelmezésében. Bevallottan nem egy koherens elméleti keret kidolgozására törekednek, hanem jellemző példákból, felvetésekből, lehetőségekből válogatnak; írásukban számos gondolatébresztő részletre lelhetünk, ha nem is mindig világos közöttük az öszszefüggés az olvasó számára. 
Sorvezetőjük Baudelaire A modern élet festője címú múve, valamint Adam Phillips pszichoanalitikus és Judith Clark divatkurátor közösen rendezett kiállításának koncepciója, ami az öltözködést a szorongás-kívánság-vágy fogalmai mentén írta le. Továbbá a magyar szerzőpáros bevonja vizsgálódásai körébe a Je Suis Belle kollekcióit, projektjeit, amelyeknél a tudatalatti-tudati folyamatok és múvészi hatások összetett viszonyát veszik szemügyre. Végül utalnak a gyerekkor, valamint az anya-gyerek kapcsolat öltözködést befolyásoló hatásaira, aminek feltárása új szempontokat kínál a divat értelmezéséhez (vö. Smith 2017).

Hermann Veronika komoly elméleti apparátust felvonultató, ugyanakkor világos és jól strukturált tanulmánya a hipszter és a punk történetileg módosuló kategóriáit vizsgálja abból a szempontból, hogy hogyan olvadtak bele a mainstream tömegkultúrába és -fogyasztásba. Hermann az identitás alatt nem adottságot, hanem folyamatot ért, és bevonva Foucault az én technológiáiról szóló elméletét, testi és kulturális gyakorlatok összességeként értelmezi azt.

Végigveszi a hipszter lázadó ellenkultúrájának alakulását a beatnemzedéktől kezdve a polgárjogi mozgalmakon keresztül egészen napjainkig, amikor már jól szituált, tudatosan fogyasztó, közép- és felső-középosztálybeli fiatalokat jelöl. A szerző előképüket a városhoz való viszony, a mobilitás és a fogyasztás tekintetében a 19. századi kószáló (flâneur) alakjában látja. A punkok esetében pedig arra a folyamatra hívja fel a figyelmet Vivienne Westwood tevékenységén keresztül, ahogy a radikális bricolage gyakorlata beépül az haute couture világába (anyagkombinációk, szabásvonal, feliratok). A szerző érvelése szerint mind a hipszter, mind a punk - most nevezzük így az egyszerúség kedvéért - mozgalom bizonyos elemei presztízstermékekké váltak, amelyek kulturális kifejezőeszközökként már nem kritizálják a társadalmi hierarchiát, hanem maguk is részt vesznek a gazdasági és a kulturális egyenlőtlenségek fenntartásában.

A Divat, egyén, társadalom címú tanulmánykötet tetszetős kiállítású, jegyzetapparátusa gondos, képválogatása a cikkekhez kapcsolódó, jól kiegészítve, illusztrálva az azokban foglaltakat. A szélesebb olvasói kör megcélzásával állhat összefüggésben, hogy a szövegekben előforduló nevekhez, fogalmakhoz magyarázatot fúznek lábjegyzetben, ami a témát kutatóknak sem haszontalan. Továbbá a kötethez név- és tárgymutató, kép- és forrásjegyzék, összesített bibliográfia, tanulmányok rezüméje, valamint a szerzőkről szóló rövid biográfiai jegyzet is tartozik. Az írások között van mikroelemzés, diskurzusanalízis, nagyobb kutatás részlete, elméleti felvetés, esettanulmány, áttekintés. Témákban, megközelítésekben, szempontokban és módszerekben változatos képet mutatnak, ami a divattörténeti kutatások sokféleségéről és sokrétűségéről, illetve a többi tudományterülettel való gyümölcsöző kapcsolatairól tanúskodik. Ebből kifolyólag a kötet tanulmányainak köszönhetően a divat más-más értelmezése és más-más funkciója kerül előtérbe, azaz a ruha lehet politikai eszköz, családi ereklye, menedék, fantazmagória, artefaktum, tucattermék, kereskedelmi áru, a személyes és a társadalmi reprezentáció tere, és a sor még folytatható, amely jelentések sosem statikusak, magukban állók, hanem folyamatosan változó konstellációkat alkotnak; ütköznek, kereszteződnek, kombinálódnak egymással.

A szerzők bemutatásától el kellett tekintenem, hiszen, ha csak F. Dózsa Katalin iskolateremtő munkásságát nézzük, pusztán annak érdemi ismertetése, hovatovább értékelése szétfeszítette volna e recenzió kereteit, és akkor még nem esett szó a többiekről, akik az adott téma szakértőiként szintén tekintélyes tudományos előélettel rendelkeznek. Mindazonáltal a kötet végén található bibliográfia informálhat minket a szerzők és más 
hazai kutatók korábbi divattörténeti múveiről.

A 2015-ös divattörténeti konferencia és az annak a válogatott anyagát tartalmazó Divat, egyén, társadalom című tanulmánykötet abból a szempontból hordozza a fordulópont ígéretét a magyar divattörténet számára, hogy lépést tesz az évtizedek óta folyó divattörténeti kutatások összefogása, a különböző kiadványokban, katalógusokban, disszertációkban, periodikákban (pl. Folia Historica) és folyóirat-különszámokban (pl. Korunk, Korall) elszórtan megjelenő kutatási eredmények és az új megközelítések összegyújtése, valamint e tudományág hazai önartikulációja és újradefiniálása felé, ami remélhetőleg további közös konferenciákra, szakmunkákra, együttmúködésekre, kutatási projektekre fog ösztönözni.

\section{HIVATKOZÁSOK}

Bass-Krueger, M. - Kurkdjian, S. (2016) « Je t’aime, moi non plus » - Compte-rendu du colloque "Échanges Franco-Allemands dans la Mode » Paris, 6-7 octobre et Berlin, 10-11 octobre 2016. Regards croisés, 6, 106-113.

Buckley, Ch. - Fawcett, H. (2002) Fashioning the Feminine. Representation and Women's Fashion from the Fin de Siècle to the Present. London - New York: I. B. Tauris.

Földes J. (é.n.) A halászó macska uccája. Budapest: Athenaeum.

Smith, R. (2017) My Mother, Dress, and Dementia. Elérhető: http://www.fashionstudiesjournal.org/commentary/2017/5/11/mymother-dress-and-dementia [Letöltve: 2017-05-30] 